\title{
Substance P-Saporin
}

National Cancer Institute

\section{Source}

National Cancer Institute. Substance P-Saporin. NCI Thesaurus. Code C107682.

An agent composed of substance $\mathrm{P}(\mathrm{SP})$ conjug ated to the ribosome-inactivating protein and neurotoxin saporin (SAP), isolated from the seeds of the plant Saponaria officinalis (SP-SAP), with potential analgesic activity. Upon administration, SP-SAP targ ets the SP receptor, neurokinin-1 receptor (NK-1R), located on neurons. When SP-SAP binds NK-1R and the receptor/conjug ate complex internalizes, the saporin moiety inactivates ribosomes and prevents protein synthesis, which causes cell death, destroys NK-1Rexpressing nerves and decreases pain perception. 